\title{
Impact of COVID-19 and Rural Health Care System: A Case Study of Nadia District in West Bengal
}

Debesh Bhowmik $^{1 *}$

${ }^{1}$ Former Principal and presently Research Professor, Lincoln University College, Malaysia

DOI: $10.36348 /$ sjef.2022.v06i01.001 | Received: 29.11.2021 | Accepted: 04.01.2022 | Published: 07.01 .2022

*Corresponding author: Debesh Bhowmik

Former Principal and presently Research Professor, Lincoln University College, Malaysia

\section{Abstract}

Rural health care system is closely related with the economic growth through boosting human capital accumulation that can be able to alleviate poverty. To what extent rural health care would manage and confront with covid-19 situation in the District of Nadia under West Bengal is the central area of this article. Both the public and private medical facilities had been faced with the situation of pandemic with poor infrastructure of rural health care systems through sub-divisional hospitals, PHC, CHC, HSC and other health care units in Nadia where both success stories and failures were simultaneously evident. The state government along with NRHM must attempt to upgrade and modernize the rural health care units spending higher health expenditure and recruiting more health professionals with doctors to fight against covid-19 type of pandemic and other emergencies.

Keywords: covid-19, rural health, Nadia district, rural health care units.

Copyright $\odot 2022$ The Author(s): This is an open-access article distributed under the terms of the Creative Commons Attribution 4.0 International License (CC BY-NC 4.0) which permits unrestricted use, distribution, and reproduction in any medium for non-commercial use provided the original author and source are credited.

\section{INTRODUCTION}

Rural health has close association with economic development since healthy population can increase productivity as well thus higher per capita income. On the other hand, if more investment in rural health occurs so that health index will improve by which HDI in rural areas may also enhance and as a result of that economic growth will stipulate. Therefore, human capital development is the key factor of economic growth which was developed by Lucas and Romer (1990). If rural health expenditure is being increased then life expectancy at birth of rural people will increase that can boost economic growth in future. Bhowmik (2020) verified by an econometric model in India during 1990-2017 that health expenditure has long run causality with life expectancy at birth and short run causality with HDI and life expectancy at birth in India. Bhowmik (2019) also examined in ASEAN bloc that one percent increase in health expenditure per year led to $0.0124 \%$ increase in HDI per year in ASEAN during 1990-2016. Moreover, Bloom, Canning and Graham (2003) concluded that the longer life expectancy is associated with a higher saving rate. Therefore, human capital affects multidimensionally in the area of growth, technology and innovations. The importance of rural health care system if classified at least in disaggregative analysis has close relation with the productivity in food-grains production or as a whole gross domestic agricultural product which is a part of GDP.

If the urban drift is to be reversed then focus is to be needed on improving the rural health of the people even in remote areas so as to stop the poverty-ill healthlow productivity downward spiral. In addition to that mental health of rural people with or without pandemic is to be nourished by the government rural health reform measures where provision of health service in rural and remote areas is significantly affected by limited funding and other resource constraints. The delivery of health services in rural areas must be specific to the rural context which is rather different from cities.

National Rural Health Mission emphasized to strengthen public health management and services delivery in the country. It has provided a female health activist in each village headed by Panchayat. It tries to upgrade rural hospitals for effective curative care and makes measurable and accountable through Indian Public Health Standard. It attempts to integrate vertical 
Debesh Bhowmik., Saudi J Econ Fin, Jan, 2022; 6(1): 1-6

health and family welfare programme. Its goal is to optimize fund utilization and infrastructure and improve rural health care delivery system. It seeks decentralization of progress for district management of health to eliminate disparities between districts and states. It has action programme to revitalize ASHA workers strengthening sub-centers, $\mathrm{PHC}$ and $\mathrm{CHC}$ through improving rural health infrastructure. Irrespective of the mission, it is to noted that rural health delivery system should be modernized during the process of reform in health planning towards the village artisans, workers of fisheries, mining and forestry from which a vital contribution in GDP share comes from $\left[{ }^{1}\right]$.

During the covid-19 pandemic situation, the Rural Health Care Foundation has done a great service in 8 districts within 17 centers in West Bengal in supplying food, masks, soaps, medicines to the distressed people $\left[{ }^{2}\right]$.

The cruelty and devastation of covid-19 virus in India vis-à-vis the world have teach the governments and the people that both private and public health care systems in India are not quite adequate to confront with this pandemic situation. More health education, training, research and infrastructure are needed for which additional investment in health is urgent for becoming healthy people. In this paper, the author endeavors to describe the rural health care system and the covid-19 scenario in the district of Nadia under West Bengal as a case study with the help of some internet reports, census reports and some valuable studies.

\section{Important studies}

Health Policy Institute (n.d.) had observed that [i] rural population is somewhat less healthy than urban population,[ii] chronic conditions are somehow more common among adults in rural areas,[iii]adults in rural areas experience higher rates of limitations,[iv] risky health behaviors are somewhat more common among adults in rural areas,[v] adults in rural areas are less likely to be tested for chronic conditions,[vi] fewer health care providers are available in rural areas.[vii] telemedicine can bring services to undeserved areas,[viii] medical insurance is generally less in rural areas.

Duggal (2002) proposed to establish right to health and health care equating Directive Principles with fundamental rights through constitutional amendments incorporating a national health act with generating political commitments along with equitable redistribution of existing health resources. State should accomplish bloc level funding with increasing per capita basis giving local government autonomy setting

\footnotetext{
${ }^{1}$ https://nhm.gov.in/nrhm

${ }^{2}$ https:/www.ruralhealthcarefoundation.com
}

up medical council regulating private sector with integrating ESIS and CGHS.

Koller (2019) concluded that there is rural urban health inequities which interact with income quintiles. These inequities are the resultant effects of weaker health system in rural areas where rural poor faced adverse social and environmental factors. Rural poverty can be eliminated through strengthening rural health system. Chakraborty (2021) proposed that E-PPP model can be implemented by both private and public sector which can fulfill common health care goals providing more modern infrastructure and medical services regardless of location. Patil et al. (2021) emphasized that a cloud based computing information system can be easily accessible in PHC and subdivisional hospitals in rural areas that can minimize cost and time with maximizing facilities in utilizing resources in developing health care system in rural areas in India. Mohan and Kumar(2019) recommended that [i]India should set up more rural medical colleges,[ii] establish more rural training for rural health professionals,[iii] set up more empowered group to improve training,[iv] an efficient PHC team for health and wellness to develop skill,[v] PMJAY should cover primary healthcare in accordance with $\mathrm{PHC}$,[vi] higher finance for PHC is urgent.Academy of Family Physicians of India(2018) recommended that[i] investment in primary health care should be increased to $2.5 \%$ of GDP,[ii] people should be entitled for insurance under National Health Protection Scheme referred by PHC,[iii] PHC team for health and wellness should be responsible and accountable and they should be adequately supported through skilling ,supervision and technologically equipped and linked with higher authority,[iv] they should be given good training to produce rural primary nurses,[v] Government should allocate a large proportion of post graduate seats for family centred care with rural immersion,[vi] district health care unit require more rural medical colleges,[vii] need more high quality training professionals for managing $\mathrm{PHC}$ and [viii] to set up empowered group for improvement in training health care professionals. Desai (2021) admitted that in India $\mathrm{PHC}$ is the essential component of effective COVID-19 response and recovery, especially in mitigating the disastrous wave of severe infections that now threaten to break down acute care hospital systems. Despite weaknesses within India's PHC system, it can still be tangibly leveraged in this moment to play a critical role in mitigating the ongoing crises. Even, the centres engaged to challenge the second wave and the vaccination drive although their capacity is low and health workers are limited to mobilise the actual situation.

\section{Rural health care scenario}

Basically, rural healthcare system in India is insufficient, inadequate, and bleak and had been suffering from poor infrastructure where villagers don't 
Debesh Bhowmik., Saudi J Econ Fin, Jan, 2022; 6(1): 1-6

fully rely and dependent to save their lives. Generally, rural health care system in India is covered with the assistances of health Sub-Center, Primary Health Center and Community Health Center irrespective of AYUSH and subdivisional and district hospitals.

Let us illustrate first the primary introduction of Nadia district which consists of 5167600 populations whose $72.2 \%$ live in rural areas. The male population is 2038943 as against 1896183 of female. The population growth rate of rural is estimated as $2.9 \%$ per year. The male literate people are 1878866 in comparison with 1601689 of female. Hindu population consists of $72.2 \%$ and $26.8 \%$ are Muslim. Male workers are $53 \%$ and the female workers are $7.6 \%$. Nadia district is a developed region because its southern part is very close with Kolkata. It grows food-grain production well with other crops and it has industrial production also. The contribution of district domestic product of Nadia varies $8-10 \%$ of the gross state domestic product of West Bengal. Its cultural heritage is rich and its education facilities and medical facilities are high compared with other rural areas in West Bengal. Nadia district has four subdivisions with 18 blocs with 9 municipalities and 187 gram panchayets. In showing education infrastructure it is noted that it has 2620 primary schools,625 upper primary schools,117 high schools,293 higher secondary schools, 18 colleges, 2 universities, 13 B.Ed. colleges, 2 law colleges, two medical college,5 engineering colleges, 7 business management institutes and 282 bank branches etc. In case of medical infrastructure, Nadia is advanced with other districts. It has one district hospital, two subdivisional hospitals, three state general hospital, 14 rural hospitals, 93 primary health centers, 42 community health centers, 469 health sub-centers respectively. There are 233 MBBS doctors and 362 degree holder doctors have been working in hospitals and primary health centers constantly in this district. Besides there are 1664 medical practitioners without degrees and 410 traditional medical practitioners have been involved in medical service in Nadia. Above all, 673 medical shops and 35 charitable hospitals have been serving to the lives of district people earnestly $\left[{ }^{3}\right]$.

In West Bengal, health sub-centers has covered the average population of 6069 in comparison with 68843 in primary health centers and 180615 in community health centers in which 8.07 square $\mathrm{km}$ of rural area is covered by health sub-centers,91.60square $\mathrm{km}$ by primary health centers and 240.32 square $\mathrm{km}$ is covered by community health centers as on 31March, 2020.In West Bengal, 1910 posts of MBBS doctors have been sanctioned in all district hospitals and 2493 for subdivisional hospitals but 804 doctors are in position in district hospitals and 2130 doctors have been serving in all subdivisional hospitals. The para medical staff in district and subdivision hospitals were sanctions
1004 and 3165 respectively but the actual positions are 865 in district and 2822 in subdivisional hospitals respectively. Therefore, there are huge short fall of doctors and para medical staffs in different districts and subdivisional hospitals which compels the state to produce more doctors and para medical staffs for serving health care in rural areas of West Bengal. To judge the rural health care in rural tribal areas in West Bengal, it is to note that there are 2889 health subcenters,283 primary health centers and 105 community health centers respectively. It is also noted that in those tribal areas of West Bengal, there is 389 doctors were sanctioned but only 332 were in position and 566 health assistants are required but only 146 were sanctioned and even for health workers in tribal areas, there are required 2889 posts but only 2070 posts were sanctioned up-till $31 / 3 / 2020$. So, no doubt that there is a bleak scenario of rural health care infrastructure in tribal areas of West Bengal $\left[{ }^{4}\right]$.

In Nadia district, private hospitals have many contributions towards medical facilities which were provided to the distressed people of Nadia whether they are rural or urban although their infrastructure was not fully equipped with modern medical technology and apparatus. Yet, the rural health modalities were dependent on those hospitals although the cost of health care was high which was beyond reach to the rural poor. Yet, the rural poor often take opportunity from them in times of emergency. The names of those private hospitals are the following:[1] Municipal Health Care Centre, Krishnagar [2], Suraksha Diagnostic, Krishnagar [3], Rogi Sahayata Kendra, Chakdaha [4], Gayeshpur Hospital [5], Shefa Eye Clinic and Nursing Home, Krishnagar [6] Baishakhi Hospital, Kalyani [7], Barnia Hospital, Kalyani[8] Sunview Nursing Home, Kalyani [9] Shalua Red Cross Hospital, Palpara,[10] Jadav Dutta Hospital, Ranaghat [11], Bagula Rural Hospital [12] Majumder Millenium Nursing Home, Kalyani [13], Mediview Diagnostic Centre, Kalyani [14], Sri Mayapur Community Hospital [15], SNR Carnival, Kalyani [16], Jaymala Memorial Hospital, Kalyani [17], Mary Immaculate Hospital, Krishnagar, [18] Arshi General Hospital, Ranaghat [19], Sambath Hazra Memorial Hospital, Kalyani [20], Minerva DSA Hospital, Bhatjangla [21], Glocal Hospital, Krishnagar [22], Manorama Hospitex, Ranaghat.

On the other hand, there are 40 reputed private nursing homes in Nadia district whose service to the rural people as well as urban people are really appreciable although their infrastructure are not up to the mark to modern medical care and for complex diseases. However, they save lives of district citizens with care although the cost of nursing is very high and sometimes beyond reach to the rural poor who therefore, generally prefer to government hospitals. The names of the notable nursing homes can be mentioned 
Debesh Bhowmik., Saudi J Econ Fin, Jan, 2022; 6(1): 1-6

below:[1] Central Nursing Home, Krishnagar [2] Sevayan Nursing Home, Nabadwip [3]Bhabani Nursing Home, Ranaghat [4]. Kalyani Nursing Home, Kalyani,[5] Central Nursing Home, Ranaghat, [6] Nabadwip Nursing Home [7] J.M. Carnival, Kalyani [8] Green View Nursing Home, Chapra [9], Lifecare Nursing Home,Bethuadahari, [10] Modern Nursing Home, Palasi [11], Medicare Nursing Home, Barnia.

\section{What was actually happened?}

During the period of Lockdown which was declared by the Government, the normal activities of rural as well as other people were fully disrupted. All shops were closed, industry, educational institutions, trains, buses were stand still. Peoples' movement was fatally disturbed due to no transportation. Rural or local doctors stopped to care the patients. No doctors who usually see the rural patients or other patients were able to come to their personal chambers or outdoor centres. Only medical shops and other medical care units were open. Government encouraged the people to come to hospitals or primary health centres to treat their ails. But the demand for treatment from rural people who suffered from various diseases was unable to treat because they have to test RTPCR for corona to admit in the hospital. If the report is negative, the government hospitals or PHC would treat them if there is vacant bed. If the result comes positive then they were shifted to quarantine centres or advised to live safely at home through quarantine along with medicines. So, there were crises of normal as well as treatment for corona. The rural households became helpless, fearful and lived with uncertainty without proper medical facilities. The local medical practitioners, medical shop keepers sometimes treat the patients by giving medicines from their shops. Local doctors stopped their practising. So, old people, actual covid patients and other patients usually died without proper nourishment. Some rich people went to admit in private hospitals in nearest places in town or towards Kolkata. Because there are a few centres of Covid-19 patients in Nadia districts in which the infrastructure was not adequate and fully equipped and even was running without doctors with the supervision of district authority. Some quarantine centres were run through amenities of boarding for lodging as safe home. The impact of tele-medicine programme, however good for highly educated technology driven people did not succeeded in rural areas in advancing rural health care infrastructure because rural poor were non-readers of newspapers and non-users of mobile phones and even many were not equipped with television sets. Other sides of the coin were that the rural nursing home, or medial centres which have taken the opportunities of zero treatment situation have been involved with huge earnings from the covid patients. The miserable situation is that during the period of vaccination which was activated through government hospitals in subdivision or district level, the rural people stayed in ques in the hospitals till from the mid-night to get vaccine at the next day at $11 \mathrm{am}$ or
$12 \mathrm{pm}$. Sometimes, the people returned back due to nonavailability of vaccines which was not declared earlier so that they can be removed from harassment. On the other hand, the people who are capable to get vaccinated with payment from private hospitals or other organisations got vaccinated easily with listing from COWIN app. Therefore, there are unequal policies of vaccination in rural health care facilities in India where the rich are being benefited and the poor is deprived.

The rural daily workers who worked outside West Bengal or in other districts returned home by spending huge money on the way to home and became penniless or saved a little amount of money by which they were living at home under quarantine. They spent money from their old saving and ultimately, they became jobless and penniless and searched for other types of works at local area. The system "work from home" culture is well suited for top officials, engineers, officers, bureaucrats, secretaries, managers, bankers and so on who are broadly equipped with internet and provision of computers or laptops but it is inappropriate for rural labours or workers who are basically wage earners. Therefore rural unemployment was increased more rapidly than the urban unemployment. More specifically, educated unemployment was spreading less than uneducated unemployment.

\section{Covid-19 and Nadia District}

The virus of covid-19 had spread in Nadia at late than in Kolkata and Delhi because it is $70 \mathrm{Km}$ away from Kolkata and it is mainly rural area. However, the virus killed and affected many people who were not even aware of the symptoms and effects of the disease. Along with Kolkata, all the media had covered its impact and gave sufficient awareness to the people but during the period of lockdown, most of the people were in panic and restless and sleepless. Since, most of the doctors were not fully efficient on covid-19 treatment and precaution and were based on the directions and guidelines of WHO and other developed nations' activities. Some misconceptions and superstitions were moving around the village people and they were neglected at the preliminary stages for which most of the rural people suffered by fever of covid-19 but did not find any proper treatment from local doctors and were dependent on medical shops. And, finally a few citizens fell in severe stage of covid-19 and were sent to hospital for better treatment where somebody rescued and somebody died.

In Nadia district, according to government report, up-till $20^{\text {th }}$ August,2021,total 52478 people were affected by covid-19 in which 984 people were died and 6263 people were recovered from it $\left[{ }^{5}\right]$. To prevent from the impact of covid-19, Nadia District Medical Officers were following the guidelines of West Bengal integrated Covid management system run by West

${ }^{5}$ Ananda Bazar Patrika dated 20/8/2021 
Debesh Bhowmik., Saudi J Econ Fin, Jan, 2022; 6(1): 1-6

Bengal government who had provided audio-visual tele-medicines facilities and started 29 centres with their phone numbers so that every people can contact to admit the patients in hospitals. Block-wise 18 nodal officers were appointed for covid-19 management where joint-BDO were in charge whose phone numbers were given to the public via newspapers to contact for help. Eleven municipalities with nodal and Assistant nodal officers were appointed in charge of caring the covid -19 situation and their phone numbers were given to the public to contact for help. Nadia district has selected seven hospitals for covid patients who are given below $\left[{ }^{6}\right]$.

Manorama Hospitex Pvt.Ltd, Ranaghat [1, 2] JNM Hospital, Kalyani,[3] SNR Carnival Hospital, Kalyani,[4] Netaji Subhash Sanatorium and Tuberculosis Hospital, Kalyani, [5] Shaktinagar Zilla Hospital, Krishnagar,[6] Glocal Hospital, Krishnagar and [7] Hiramani Memorial Hospital, Krishnagar.

In SNR Carnival Hospital, 120 beds had been arranged and in Netaji Subhash Sanatorium and Glocal Hospital, 300 beds and 150 beds had been started for running the treatment by the initiative of government supervision. But all these centres were situated in the hearts of the towns so that rural people had faced many troubles and hardships to admit there. On the other hand, people of North 24 Parganas usually get opportunities in Kalyani hospitals because of easy availability with better facilities. Of and on, recommendations from political level and higher authorities may disrupt the opportunities of general rural mass. Other discrepancies are that there is lack of efficiency; proper training of doctors to treat covid-19 patients and the lack of infrastructure facility in the hospitals can also be mentioned. So that, emergency covid-19 patients had been referred to Kolkata where most of the cases were in danger.

Nadia district medical authority had been arranged some important quarantine centres in different places in Nadia whose names have been listed below.

Kalyani municipality, [1, 2] Collectorate, Nadia [3]. Nadia Diagnostic Centre, Krishnagar, [4] Dr. SKS Diagnostic Centre, Krishnagar, [5]Kaliganj BDO office,[6]District Office of the Minority, Krishnagar, [7] Gayeshpur Municipality, Gayeshpur,[8] Krishnagar DTC, [9] Chakdaha State General Hospital, [10] Ranaghat Town Hall, [11]Tehatta Sub-Division Office,[12] Zila Sainik Board, Krishnagar, [13] Fulia BPHC Hospital, [14] Red Cross Bhawan, Krishnagar,[15] Indian Red Cross Society, Krishnaganj, [16] Bidhan Chandra Krishi Vishwavidyalaya, [17]Navodaya Vidyalaya, Krishnagar, [18] Krishnagar Officer Swimming Club,[19] Tehatta Subdivision Hospital, [20] Red Cross Society, Debagram.
Recently Government of West Bengal had started an insurance scheme of 5 lakh of poor people for treatment in government hospitals where the holder can be benefitted if died during the treatment. On the other hand, the poor citizens of West Bengal have been allowed to hold Shwathya Sathi card if they wish to get free treatment in any government and non-government hospitals. The scheme proves the assurance of provisions of health care for the poor mass in West Bengal.

The virus Covid-19 has proved the actual capacity building of health infrastructure in rural areas, the shortage of health workers especially doctors, nurses, paramedical staff and health workers all of which could not confronted with the covid-19 pandemic and its horrors. All the rural PHC, CHC and subdivisional hospitals are less equipped with Modern technological machines for testing of diseases like corona and its proper treatment and even the doctors are less efficient to tackle the situation although they were allied with WHO and ICMR guidelines and supervisions. Usually, the PHC, CHC and Sub-Centre of Nadia did not encourage the covid-19 serious patients and they sent them to covid-19 hospitals in Nadia district whose prime responsibility was to consider the emergency covid patients to hospitals in Kolkata if necessary. After examining RTPCR test, the positive patients who are not serious, are being sent them to safe home in Nadia district by the PHC or subdivisional hospital.

\section{CONCLUSION}

In conclusion, the general facts during the covid-19 pandemic in Nadia can be summarised and are given below.

a. It was observed severe shortage of rural doctors, nurses, and medical staff in rural health centres.

b. Insufficiency of medical appliance, medicines and other equipment were normal situations.

c. Inefficiency of data collection during lockdown was evident for which all rural deaths due to covid-19 were not properly registered.

d. Acute food insecurity in rural areas was evident where public distribution system was inadequate according to needs.

e. Pandemic has worsened the treatment and delivery of pregnant women in remote rural areas.

f. General medical care for rural people have hampered immensely.

g. Migrant labour of rural areas has sent to quarantine although their earnings went off to near zero.

h. Covid-19 awareness programme in remote rural areas were neglected. No steps were taken through the rural health care units.

i. Rural poor had suffered from RTPCR test and have been suffering from scheduled vaccination programme.

j. Government did not allow private health care units in rural areas to nourish covid-19 patients except its selected centres. 
k. A new rural social health worker took opportunities during pandemic and run unfair practices.

1. Consumption expenditures of mass rural poor have been dwindled along with high burden of medical expenses.

m. It was expected that food inflation will come down in rural areas but it was happed reverse in reality. On the other hand, real wage rate had declined which inversely affected their medical expenses.

n. Rural-urban disparity widened for which rural development programme on health hampered during the pandemic.

o. No doctors were available in rural private chambers so that insecurity of life was soaring.

p. All cases of fevers, cough, respiratory problem, ashma were levelled as positive covid patients and were sent to live in quarantine centres.

q. Most of the death cases were certified as covid positive so that dead body was not given to their relatives.

r. The poor rural covid-19 critical patients who had no special communication with higher medical officers or relation with political leaders were died silently without proper medical care.

s. The propaganda of social distancing hampered the social human relationships in the society during lockdown. Every people became alone and helpless. No rural health care units or urban health care officials took initiative to help the poor people without any emergency call done by socially influential or political persons.

t. Rural people and even literary people were confused by the awareness programme through various medias and advertisements on the general symptoms and the effects of covid-19 virus.

There is no difficulty to believe that the rural health care system, its whole infrastructure, its attempts to fight the impact of covid-19 pandemic situation did not succeed fully and yet did not fail completely. The success story may encourage humanity but the causes of failures should be borne by the government alone rather general public have some duties and responsibilities. Above all, rural health care infrastructure should be renovated, modernised, pro-poor and acceptable to all in any unforeseen emergencies.

\section{ACKNOWLEDGEMENT}

In preparing this article, no fund was sanctioned by any govt/NGOs or institutions. I am responsible for all errors and omissions.

\section{Conflict of Interest} publication

There is no conflict of interest in the process of

\section{REFERENCES}

1. Academy of Family Physicians of India. (2018, August). Strengthening Primary Health Care in Rural India:
Report and Recommendations of a National Consultation. International conference on "Healing the Heart of Healthcare- Leaving No One Behind" held at India Habitat Centre, New Delhi from 26-29th April, Retrieved

from https://www.indembassyisrael.gov.in/pdf/Rural_P rimary_Care_Report_Sep05.pdf.

2. Bhowmik, D. (2019). Factors of human development index in ASEAN: Panel Cointegration Analysis. International Journal on Recent Trends in Business and Tourism, 3(1),ejournal.lucp.net

3. Bhowmik, D. (2020). Determinants of India's health expenditure: An econometric analysis. International Journal on Recent Trends in Business and Tourism, 4(1),13-23.

4. Bloom, D.E., Canning, D., \& Graham, B. (2003). Longevity and Lifecycle savings. Scandinavian Journal of Economics.105(3),319-338.DOI:10.3386/w8808.

5. Chakraborty, Iman. (2021). E-PPP model: A way to boost up the rural health care system in India. Health Vision.17/8/2021.Retrieved

from https://healthvision.in/e-ppp-model-a-way-toboost-up-the-rural-healthcare-system-in-india/

6. Desai, E., Ratcliffe, H., Bitton, A., \& Schwarz, D. (2021). COVID-19 and Primary Health Care: How can India leverage a current crisis to build a stronger future? Ariadne Labs, April 29, Retrieved from https://ariadnelabs.medium.com/covid-19-and-primaryhealth-care-how-can-india-leverage-a-current-crisis-tobuild-a-stronger-61b11683431f

7. Duggal, R. (2002). Health Financing for Primary Health Care in Rural India: Prospects and options. Draft paper for Harvard School of Public Health initiative on Right to Development, Retrieved from http://www.cehat.org/cehat/uploads/files/A\%20243\%20 Health\%20financing\%20for\%20primary.pdf.

8. Health Policy Institute. (n.d.).Rural and Urban Health. retrieved from https://hpi.georgetown.edu/rural/

9. Koller, Theadera, Swift. (2019). Rural Poverty and Health Services: Challenges and Gaps. Paper presented at Addis Ababa on WHO/HQ Expert Meeting. Retrieved from https://www.un.org/development/desa/dspd/wpcontent/uploads/sites/22/2019/03/WHO-Rural-

Health_Kollert-TheadoraSwift_1March2019@06h00.pdf.

10. Lucas, R.E. (1988). On the Mechanics of Economic Development. Journal of Monetary Economics, 22(1),342.

11. Mohan, P., \& Kumar, R. (2019, July). Strengthening primary care in rural India: Lessons from Indian and global evidence and experience. Journal of Family Medicine and Primary Care, 8(7), 2169-2172.doi: 10.4103/jfmpc.jfmpc_426_19

12. Patil, P P., Patil, A. A., \& Patil, V. V. (2021, February). Cloud Computing For Rural Health Care Development: A Social Concern. International Journal of Multidisciplinary Educational Research, 10, 2(3), 39-42. Retrieved from http://s3-ap-southeast-1.amazonaws. com/ijmer/ pdf/volume10/volume10-issue2(3)/9.pdf.

13. Romer, P.M. (1990). Human Capital and Growth: Theory and Evidence. Carnegie-Rochester Conference Series on Public Policy, 32(1), 251-286. 